\title{
CULTURAL REPORT
}

Wang Baoqiang: China's Peasant / Soldier Celebrity

Corey Kai Nelson Schultz

Film Department, University of Southampton, UK

c.schultz@soton.ac.uk; chns@berkeley.edu

[BIO - 50 words approx.]

COREY KAI NELSON SCHULTZ is a Lecturer (Assistant Professor) at the University of Southampton. He earned his $\mathrm{PhD}$ from Goldsmiths, University of London. His areas of research are contemporary Chinese visual culture and film phenomenology.

First draft received: 20 November 2018

Final draft accepted: [***] 


\section{Introduction}

Wang Baoqiang (王宝强, b. 1984) is a film star and actor-director, most recently appearing in the Chinese blockbusters Iceman (Law Wing-cheung, 2014), Detective Chinatown I and II (Chen Sicheng, 2015, 2018), and Buddies in India (Wang Baoqiang, 2016). In this article, I examine how his early roles connect to the iconic class figures of peasant and soldier that were made popular in Maoist-era propaganda, and track how his portrayal of these class figures helped establish him as a film star and a modern-day celebrity in a contemporary Chinese context. Similar to Richard Dyer's assertion that 'star images have histories, and histories that outlive the star's own lifetime' (2012, p. 3), these Maoist figures also have a long cultural life that have transcended political changes and have outlasted single lifetimes, and their importance still reverberate today. I argue that by representing these class figures, Wang has leveraged these roles to become a modern-day celebrity. To do this, I begin by briefly introducing Wang and explaining the social and ideological contexts of the peasant and soldier Maoist figures - the peasant 'everyman' and the People's Liberation Army soldier 'hero' - and then explore these figures and their iconic characteristics. First, I examine Wang's roles as peasants and rural migrants, who are naïve, honest and hardworking characters whose endurance and earnestness inspire other migrants to succeed. Then, I examine two of his soldier roles, and how they invoke the altruistic and sacrificial Maoist tropes attached to this group, as well as allude to the iconic persona of Lei Feng, a selfless Maoist soldier hero who was not only ideologically important during the Maoist era but whose image has been 'resurrected' in the contemporary period by the state to promote patriotism. I conclude by considering the use of iconic Maoist character tropes in Chinese 
celebrity studies and consider how these socio-historical and aesthetic icons intersect with modern-day celebrity.

\section{Current status}

Wang Baoqiang has received many acting awards, among them: Best Actor at the $40^{\text {th }}$ Taiwan Golden Horse Film Festival (2003), the Second Bangkok International Film Festival (2004), and the Deauville Asian Film Festival (2003) for his role in Blind Shaft (Li Yang, 2003); Best Actor at the Pacific Meridian Vladivostok Film Festival (2011), $5^{\text {th }}$ Asia Pacific Screen Awards, the $10^{\text {th }}$ Italy Asian Film Festival, and the New York Chinese Film Festival for his role in Hello Mr. Tree (Han Jie, 2011) (Li, 2013); and Best New Action Actor at the 2015 Shanghai International Film Festival for Kung Fu Jungle (Teddy Chan, 2015). Furthermore, he is famous not only for these roles but for his personal rags-to-riches success story. Born the youngest child to a poor peasant family in Dahuita Village in Hebei Province, he left home at the age of eight to study at the renowned Shaolin Temple, famous for its eponymous style of gongfu, with the intention of becoming a martial arts actor. After passing the rigorous test, he was accepted and graduated in 2000 (Wu, 2008, p. 32). At the age of 15, he moved to Beijing with only 500 Yuan (approximately $£ 50$ ) in his possession and, along with other want-to-beactors, waited outside film studios hoping to be cast, and worked on construction sites for 2025 Yuan per day to supplement his income (Anon, 2008b). In addition to his film roles, he is a successful singer (performing at the 2008 Chinese New Year's Gala, where he led a farm workers' choir) (Ping, 2013, p. 163), and has used his acting career to release a series of nostalgic popular songs, with titles such as 'My Parents are in the Countryside,' 'Count on Friends When You are Not Home,' and 'Made It or Not You Need to be Home for New Year' (Kuoshu, 2014, p. 343). In 2013, he was elected as member of the $11^{\text {th }}$ Hebei Provincial Committee of Chinese People's Political Consultative Conference (Li, 2013).

He has also, however, become increasingly famous due to his heavily publicized divorce. He and the actress Ma Rong met in 2007, were married in 2010, and have two 
children. However, Ma Rong had an affair with Wang's manager Song Zhe, who was also later arrested for embezzling Wang's finances, and Wang's and Ma's resulting breakup during the summer of 2016 became known as China's 'divorce of the decade' (Barnes, 2017). Their separation unfolded on Weibo, a Chinese social media platform with approximately 154 million daily users (BBC, 2017), when Wang posted his accusation on August 14 and then filed for divorce the next day, requesting full custody of their two children and to split their property and finances (Rudolph, 2016). The hashtag '\#WangBaoQiangDivorce’ was viewed more than 7.9 billion times on Weibo and was discussed on national television (Yan, 2016), and their ensuing divorce became one of the most discussed topics, not only that year but of all time on Chinese social media (Koetse, 2018). Ma later sued Wang for defamation, and Song's wife filed for divorce (Anon., 2016). Their separation was heavily debated online, but most online commenters supported Wang (Barnes, 2017), and Ma Rong's personal information was even doxed online by her detractors (Rudolph, 2016).

\section{Wang's Peasant Persona and His Rise to Prominence}

Wang first became famous for his roles as a peasant-turned-migrant worker and as a peasantturned-soldier - iconic figures that were symbolically important in Maoist-era China (194976). During this time, the worker-peasant-soldier classes (工农兵) were conceived as the forefront of the Communist revolution and promoted by the Chinese Communist Party (CCP) to develop the nation, and were lauded in Chinese art, literature, and film. Film especially was viewed 'as a vehicle for intellectual, moral, and political uplift', and a major 'shaper' of mass culture (Clark, 1987, pp. 9, 57), which was believed to have the potential to affect both the viewers' individual as well as collective identities and helped create a socialist state and a socialist national subject (Chen, 2003, p. 162). Thus, a 'proletarian cinema' that emphasised these figures came into being (Clark, 1987, p. 136). Although the Maoist era ended in 1979, 
these proletarian class figures still linger in the social conscious, reappearing in contemporary media. They are iconic figures and, as icons, come with ideological importance.

Wang is a peasant. He has been described as 'a representative of China's rural masses' (Kuoshu, 2014, p. 343) and as a stereotypical naïve 'humble village boy' with a smile described as 'remind[ing] many people of a farmer looking contentedly at his bumper harvest' (Liu, 2009). He is referred to as a 'grassroots star' (Rudolph 2016) and a 'farmer rising star' (Ping, 2013, p. 163), who 'still looks like a real country boy, with his local accent, plain dress style and shy childlike smiles' despite his fame (Anon, 2008a). Maxims attributed to Wang include: 'You must hold on when you are feeling down or when you feel hopeless, because success may be just around the corner' (Anon, 2008a); 'My success depends not only on good luck, but also on hard work' (Li, 2013); and 'I wanted to make my family proud of me. Even if I failed, at least I tried' (Liu, 2009), and is thus seen as 'an inspiration for others of humble origins' (Wu, 2008, p. 35). These sayings connect to Wang's real-life biography, which has been well publicised. For instance, although his poverty only allowed him to visit his family once a year during Spring Festival, he did not give up on his ambitions but persevered, and whenever he returned home, he gave his parents the money that he had earned (Anon, 2008b). When he finally 'made it', the first thing he did was to buy his parents the finest house in his home village for a reported half a million Yuan, an event that was widely circulated in the media (Liu, 2009).

Wang initially became famous due to his roles that portrayed him as a stereotypical, naïve peasant, who was kind and good-hearted, but shockingly guileless. His breakthrough came in 2002, when he was cast in the art house film Blind Shaft (Li Yang, 2003), playing the role of Yuan Fengming, a naïve teenage migrant worker who becomes the object of a murder plot whom the film's protagonists plan to kill so that they can claim his insurance. In this role, he was a young innocent; entering the workforce to support his family and save enough money so that he can go to high school, he was a guileless figure who did not see the corruption surrounding him. 
This role led to one in A World Without Thieves (2004), directed by the filmmaker Feng Xiaogang, who is famous for his commercial blockbusters. In this film, Wang again played a naïve peasant, this time a migrant worker who had travelled from Hebei to repair ruined temples in Tibet. He was an orphan and had worked diligently during his migration abroad, not even returning home to celebrate Spring Festival, saving all the money he had earned in order to help his village. He chooses to carry the money back to the village and not wire it, because he wants to save the transfer fee and because he believes in the inherent goodness of people. This decision leads to a battle between two groups of thieves - one group wishes to rob him, while the other group tries to maintain his innocence - which fuels the plot of the film. Finally, in the comedy blockbuster Lost on Journey (Raymond Yip, 2010), he also plays a naïve and bumbling migrant worker who is attempting to retrieve his lost wages. In this 'comedy of errors', he becomes part of an 'odd couple' with a selfish businessman; they literally are 'lost on their journey', and their country-bumpkin meets city-slicker antics drive the humorous plot of the film.

This naïve peasant trope, which he embodied in his early career, has a deeper cultural meaning. Before the modern era, the peasantry were viewed as 'connected' to the land, and were seen as a largely docile group that needed to be taken care of. As Feuerwerker (1998) explains, the government officials' 'mandate to rule' was viewed as dependent upon their responsibilities towards the peasantry, and thus this mandate 'was deserved only if the people's economic and moral welfare were properly attended to' (p. 11). Furthermore, in literature and art, they were viewed as 'hardworking', 'kind-hearted', 'honest' and 'wellbehaved', benign humanist qualities that made them a group to be cared for (Feuerwerker, 1998, pp. 53-54). Wang embodies these qualities in his early roles. In Blind Shaft, he works diligently at a mine, sending his earnings back to his family; he is kind and friendly to his colleagues; and when his co-workers take him to a brothel, he is shocked by the realisation where he is and refuses to participate in their vices. In World Without Thieves, his character is an orphan who has saved up his money so that he can use it to support his home village and is 
the first person to volunteer to donate blood for a stranger's health emergency on the train ride back home. And in Lost on Journey, he ends up donating all of his money to a beggar who is running a school for blind children.

Furthermore, not only is Wang a peasant in these three roles, he is a peasant migrant, referred to as a mingong - a peasant who has left his home village in search of work. He is therefore a representation of a much larger social development. After the state introduced market reforms to the socialist market economy following Chairman Mao's death - an era that became know as the Reform Era (1979 to present) - peasants migrated to urban centres to work as manual labourers. They have migrated in such great numbers that in 2015 the migrant worker population was estimated at 247 million people (China Statistical Yearbook, 2016). Wanning Sun (2012) reports that representations such as Wang's are popular amongst these migrant workers, hypothesising that these comedies not only provide 'comic relief' for the people, but also 'socially relevant but politically safe criticism which resonates with a broad audience' (p. 16). Such figures, therefore, not only represent their plight in the Reform economy, but also their agency - or lack thereof - in the new economy. For example, the work they do is usually dangerous; in 2006 , it was reported that $65 \%$ of these migrant workers were in 'Three D Jobs' - 'dirty', 'dangerous' and 'demeaning' - and accounted for more than 90\% of the nation's workplace deaths (Nielsen and Smythe, 2008, pp. 3-5).

Harry Kuoshu (2014) describes Wang Baoqiang's character as 'innocent', arguing: 'innocence can become a stage on which good and evil factions have a moral contest, where innocence aids in praising the good and condemning the evil... [and] they can easily be perceived as metaphors for asserting definite values' (p. 338). As he points out, films produced during the Maoist era featured 'innocent' characters that yielded to the CCP, and thus 'promote[d] ideological indoctrination' (p. 338). Kuoshu also argues, however, that Wang's character is unique because, although people in the contemporary era 'generally believe that innocence is hard to maintain in a corrupt society', there is still a 'nostalgia' for 
this lost state during a time of rapid social and economic change due to market reforms (p. 338). He adds 'The popularity of the Wang persona also expresses the real nostalgia for home felt by China's huge migrant population today, where the concept of home has started to be redefined from affiliating with roots to being determined by routes' (p. 342). The sheer extent of China's current migrant population means that Wang's naïve, hardworking and kindhearted peasant-migrant persona not only references the Maoist past, but also nostalgically mourns it, thus emphasizing the present's lack of stability.

\section{Wang as Soldier}

A similar nostalgic state can be found in his roles as a soldier. In 2007, Wang appeared in a TV series titled Soldiers Sortie, in which he played the role of Xu Sanduo - another naïve peasant, but this time one training to become a soldier. The soldier is an ideologically potent class figure. During the Communist Revolution, the People's Liberation Army became famous for assisting the communities in which they were stationed by helping them to increase food production and also assisting in developing local industry (Landsburger, 2014b). They were largely seen as a benign force by the populace, as the PLA stipulated that the soldiers should not mistreat the people but rather 'help them whenever possible' (Wei, 2012, p. 235). During the Maoist era that followed, the soldiers protected the nation and defended the people, not only by securing the borders but also through their work in national environmental protection, disaster relief, medical assistance in impoverished areas, and domestic security (Blasko, 2006, pp. 211-213). Furthermore, recruitment into the military became a method of economic and social advancement for the rural poor, by providing training, skills, and status (Landsberger, 2014a), and, after they were demobilized, soldiers would return to their hometowns and become social, economic, and political assets to their communities (Shichor, 1996, p. 74). 
In the series, $\mathrm{Xu}$ is first represented as a simple but hardworking rural teenager who has been raised by his father and two older brothers. He is bullied by his peers and beaten regularly by his alcoholic father. His father attempts to enlist each of his sons into the PLA because it would provide training and advancement, but the two older brothers are not accepted; thus, Xu Sanduo is his last hope. Xu Sanduo, however, is shy, passive, and clumsy, and is initially rejected by the visiting PLA recruiter. The recruiter, however, takes pity on Xu when he hears him being beaten by his father, and accepts him into his troop. During training, $\mathrm{Xu}$ is comically portrayed as inept; he cannot stand correctly, is unable to do simple marching drills, and comes across as a humble simpleton, whose 'strong regional accent, lack of formal education or family support makes him a hopeless recruit - leading to some hilarious antics and gut-wrenching moments' (Wood, 2013). But, like the aforementioned peasant character tropes, he is 'hardworking', 'kind-hearted', 'honest' and 'well-behaved', and it is these qualities that end up inspiring other members of his troop. For instance, although transferred to the most inferior squad after he completes the first round of his training, he does not give up like the other squad members, but remains loyal to the army: for example, he continues to practice his marching, improves the road to the compound in his spare time, does the other soldiers' chores, and remains friendly and polite when other disparage him.

Soldiers Sortie became hugely successful, and Wang's role made him a household name in China, as well as 'the most poplar actor on the Chinese mainland' (Anon, 2008b). Furthermore, he was especially popular amongst fans of the Chinese military, inspiring people to enlist (Wood, 2013). In this role, Wang is described as a 'country bumpkin', but due to his 'simple personality, sincerity and persistence in doing things' becomes one of the best soldiers in his unit (Anon, 2008a). He is someone who 'chose to work hard and challenge himself because it was the right thing to do', and thus people who are hardworking were commonly referred to as being 'like Xu Sanduo' (Wood, 2013). In this role, Wang as Xu Sanduo 'became a symbol of persistence and honesty which leads to success' (Anon, 2008b). 
He received the 'Most Favorite Actor in a TV Series' award in 2007 by the website Sina.Com (Anon, 2008a), and according to a survey conducted by PCPOP.com in 2007, was voted as having the most important public influence, since 'he represents the heart of rural China and gives hope to hundreds of thousands of young people who are striving for a better life' (Anon, 2008a), due to his rags to riches personal story. Both his role in this TV series as well as his personal history are promoted as exemplars for Chinese youth (Anon, 2008a); as he declares in the TV series, a saying that he has since made famous, 'To live well is to do meaningful things, and to do meaningful things is to live well' (Tang, 2008), thus emphasising the importance of living altruistically. This is therefore a shift from the earlier peasant-migrant roles that nostalgically looked to the Maoist past; instead, it promotes individual effort and altruism to inspire the present.

This representation was also enhanced in the film Assembly (2007), also by Feng Xiaogang. Unlike his role in Soldiers Sortie, this is not a comedic role; rather, he plays a soldier named Jiang, who not only protects his unit through his skills as a sniper, but also saves the wounded and dies by sacrificing himself to protect his fellow soldiers. The film is set in the 1940s during the Chinese Civil War, and his troop, the Communist $9^{\text {th }}$ Company, is reduced to a small band of men, which is vastly outnumbered by the Nationalist army. He is devoted to the troop leader, as well as the men in his unit. For example, when the leader's wristwatch is damaged in the fighting, Jiang and another soldier risk their lives to retrieve another one from the battlefield, and when the other soldier is critically insured, Wang carries him back and tries to keep him warm as he is dying. Furthermore, he ultimately sacrifices himself to save his troop; after he is injured, he carries a bomb to another advancing tank and blows up both himself and the tank.

Both soldier representations - although the first comic and the second tragic emphasise the qualities of determination, loyalty and sacrifice associated with the soldier figure. These qualities connect to the figure of Lei Feng, the apocryphal peasant-turned PLA 
model soldier, who was made famous due to his acts of altruism and patriotic loyalty. Lei Feng was born in 1940 to a poor family in Hunan Province, and was orphaned after his father was allegedly tortured to death by Japanese soldiers and his mother committed suicide after being raped by a landowner's son (Jeffreys and Su, 2016, p. 34). 'Adopted' by the PLA, he later worked in state-building projects in agriculture and energy, and then joined the army and 'committed his life to alleviating the hardships experienced by the Chinese people' (p. 34). Dying in an accident in 1962 when only 22, the state media began to circulate inspirational entries from his supposed diary in order to encourage people to model his behaviour (p. 33). Promoted as the 'rustless screw' by the state-controlled media, he wrote in his diary 'I will be a screw that never rusts and will glitter anywhere I am placed,' thus becoming an eternal, never-tarnishing tool of the Party (Wright, 2003, p. 102), and a model for emulation (Denton, 2014, p. 157). The apocryphal diary also contained sayings famously attributed to him, which included: 'I live to improve the lives of others' and 'I live to serve the people wholeheartedly' (Jeffreys and Su, 2016, p. 34). During the Cultural Revolution (1966-1976), his story was promoted by the CCP 'as the epitome of socialist personhood - altruistic, diligent, thrifty, self-effacing and motivated by love of the CCP, the PRC, and the Chinese people,' (p. 35) and the state began a 'Learn from Comrade Lei Feng' campaign due to his qualities of hard work, frugal living, generosity, and studying the works of Mao Zedong (p. 35).

Lei Feng's promotion ended with the death of Mao Zedong in 1976, but his iconography and importance still remained. In fact, as Jeffreys and Su argue, the figure of Lei Feng has become a 'postsocialist celebrity' - a former socialist figure in the post-Socialist context of China brought on by economic reforms (p. 32). As they explain, the state media again used Lei Feng's image in 1981 to advocate for 'socialist spiritual civilization,' a stateled concept of that combined socialist values with the market economy 'to promote political stability and ethical-cultural development in the context of rapid social change,' and was later used in the 1990s to advocate for the nation's rejuvenation through patriotism, austerity, hard 
work, and innovation, and promote 'socialism with Chinese characteristics' (combining socialism with capitalism) (Jeffreys and Su, 2016, p. 37). In the 2000s, his eponymously titled film from the 1960s was re-released, a children's animated series about his life was created, and a television series about him was aired (p. 38). Furthermore, in 2012 Lei Feng was used in a state-led campaign to promote volunteering, and in 2013 'Lei Feng Awards' were given to CEOs and entrepreneurs in recognition of their public service (p. 46). Chinese Communist Party members are required to study Lei Feng, and the Ministry of Education stipulates that elementary and middle school 'moral education' modules must include activities inspired by

Lei Feng (Mattis, 2012, p. 2). This propaganda campaign is still continuing; during June 2018 whilst I was on a research trip in Chengdu, I came across several posters in the city declaring ‘We all are Lei Feng: in our jobs, we all are diligent screws' (我们都是雷锋: 都在平凡的岗

\section{位上认认真真地一颗螺丝钉).}

Thus, we can see how many of the characters Wang has played have not only embodied stereotypical characteristics of the peasant and soldier figures, but has also been linked in the Chinese imaginary to the altruistic and sacrificial qualities of Lei Feng. Wang has therefore been aligned not only with the peasant 'innocent' but also this iconic and celebrated personality. In fact, when the TV series based on Lei Feng planned to feature the athlete-turned-actor Tian Liang in the main role, some of Lei Feng's former comrades issued a statement that Tian was not appropriate for the role, and instead advanced the possibility of three other actors taking the lead, among them Wang Baoqiang due to his previous performance as Xu Sanduo (Anon., 2009).

\section{Conclusion}

In this article, I have briefly examined the Maoist class figures of the peasant and the soldier and the iconic persona of Lei Feng, and have analyzed how Wang Baoqiang is seen as a 
contemporary film star who is embodying these figures' characteristics. Like Richard Dyer's aforementioned statement 'star images have histories, and histories that outlive the star's own lifetime' (2012, p. 3), the Maoist figures too have similar histories that continue to resonate in the contemporary period. By representing these past figures in his early roles and using their cultural importance to become popular, Wang Baoqiang reveals the continuing significance of these Maoist symbols in present-day China and the part they played in 'making' a contemporary Chinese celebrity. 


\section{Bibliography}

Anon, 2008a. Dreams do come true [online] Beijing Review.Com.Cn. Available from http://www.bjreview.com.cn/print/txt/2008-02/15/content_99720.htm [Accessed 2 December 2017]

Anon, 2008b. Wang Baoqiang, dream comes true [online] CRI English. Available from: english.cri.cn/4406/2008/01/02/1701@310094.htm [Accessed 7 September 2013]

Anon, 2009. 70 Lei Feng comrades boycott Tian Liang, elect Wang Baoqiang to perform Lei Feng [online] China.Com.Cn. Available from www.china.com.cn/culture/xt/200904/03/content_17546738.htm [Accessed 13 February 2018]

Anon, 2016. Beijing court accepts divorce filing by famous Chinese actor [online] (August

15) China Daily. Available from http://www.chinadaily.com.cn/china/201608/15/content_26482086.htm\#iscomment [Accessed 2 March 2018]

Barnes, Richard, 2017. China's most-discussed love triangle: Wang Baoqiang, Ma Rong and Song Zhe [online] What's On Weibo.Com (September 16). Available from: https://www.whatsonweibo.com/chinas-discussed-love-triangle-wang-baoqiang-marong-song-zhe/ [Accessed 15 January 2018]

BBC News, 2017. Twitter user numbers overtaken by China's Sina Weibo [online] (May 17). Available from: http://www.bbc.co.uk/news/technology-39947442 [Accessed 15 January 2018]

Blasko, Dennis J., 2012. The Chinese army today: transition and transformation for the $21^{\text {st }}$ century. London: Routledge.

Chen, Tina Mei, 2003. "Propagating the propaganda film: the meaning of film in Chinese Communist Party writings, 1949-1965.” Modern Chinese Literature and Culture 15, no. 2 (Fall 2003): 154-193.

China Statistical Yearbook, 2016. 2-3 Floating Population. Available from: http://www.stats.gov.cn/tjsj/ndsj/2016/indexeh.htm [Accessed June 18, 2017] 
Clark, Paul, 1987. Chinese cinema: culture and politics since 1949. Cambridge: Cambridge University Press.

Denton, Kirk A, 2014. Exhibiting the past: historical memory and the politics of museums in postsocialist China. Honolulu: University of Hawai'i Press.

Dyer, Richard, 2004. Heavenly bodies: film stars and society, $2^{\text {nd }}$ ed. London: Routledge. Feuerwerker, Yi-tsi Mei, 1998. Ideology, power, text: self-representation and the peasant 'other' in modern Chinese literature. Stanford: Stanford University Press.

Jeffreys, Elaine and Su Xuezhong, 2016. Governing through Lei Feng: a Mao-era role model in Reform-era China. In David Bray and Elaine Jeffreys, eds. New mentalities of government in China. London: Routledge, 30-55.

Koetse, Manya, 2018. Why Weibo and Chinese celebrities are put into the naughty corner by China's cyberspace administration [online] What's On Weibo.Com (January 30). Available from: https://www.whatsonweibo.com/why-weibo-and-these-chinesecelebrities-are-put-into-the-naughty-corner/ [Accessed 7 February 2018]

Kuoshu, Harry, 2014. Configuring innocence: China and Italy, Wang and Masina personas. Journal of Italian Cinema \& Media Studies, 2 (3), 335-350.

Landsberger, Stefan, 2014a. People's Liberation Army. ChinesePosters. Net. Available from: http://chineseposters.net/themes/pla.php [Accessed 10 January, 2014]

Landsberger, Stefan, 2014b. People's Liberation Army II. ChinesePosters.Net. Available from: http://chineseposters.net/themes/pla-2.php [Accessed 10 January, 2014]

Li Jinrong, 2013. Wang Baoqiang, from screen to political stage [online] People's Daily Online (January 25). Available from: english.people.com.cn/90782/8107658.html [Accessed 7 September 2013]

Liu Wei, 2009. Actor Wang Baoqiang rises from rags to riches [online] China Daily (July 30). Available from: http://www.chinadaily.com.cn/china/200907/30/content_8491740.htm [Accessed 2 July 2013). 
Mattis, Peter, 2012. Another Lei Feng revival: making Maoism safe for China. China Brief 12 (5), 1-3.

Nielsen, Ingrid, and Russell Smythe, 2008. The rhetoric and the reality of social protection for China's migrant workers. In Ingrid Nielsen and Russell Smythe, eds., Migration and social protection in China. Singapore: World Scientific, 3-13.

Ping Fu, 2013. Encircling the city: peasant migration in contemporary Chinese media. In Kuo Chisheng, ed. Contemporary Chinese art and film: theory applied and resisted. Washington, D.C.: New Academic Publishing, 151-165.

Rudolph, Josh, 2016. Minitrue: don't hype actor's affair accusations [online] China Digital Times (August 22). Available from: https://chinadigitaltimes.net/2016/08/minitruedont-hype-actors-affair-accusations/ [Accessed 14 January 2018]

Shichor, Yitzhak, 1996. Demobilization: the dialectics of PLA troop reduction. The China Quarterly (146), 336-359.

Sun Wanning, 2012. Screening inequality: injustices, class identities, and rural migrants in Chinese cinema. In Klaus Mühlhahn and Clemens von Haselberg, eds. Chinese Identities on screen. Zurich: Lit Verlag, 6-20.

Tang, Yuankai, 2008. Being myself [online]. Beijing Review.com.cn. (February 28). Available: http://www.bjreview.com.cn/special/2008-02/25/content_101176.htm [Accessed 2 December 2017]

Wei, William, 2012. 'Political power grows out of the barrel of a gun': Mao and the Red Army. In David A. Graff and Robin Higham, eds. A military history of China. Lexington: University Press of Kentucky, 229-248.

Wood, Peter, 2013. 'The Spirit of Xu Sanduo: the influence of China's favorite soldier.' China Brief, 13 (5). Available from: https://jamestown.org/program/the-spirit-of-xusanduo-the-influence-of-chinas-favorite-soldier/ [Accessed 4 November 2017].

Wright, Daniel B., 2003. The Promise of the Revolution: Stories of Fulfilment and Struggle in 
China's Hinterland. Lanham: Rowman and Littlefield.

Wu Yueming, 2008. Every dream can come true. China Today (February), 32-35.

Yan, Alice, 2016. Divorce of celebrities sparks talk about state of modern marriage in China [online] South China Morning Post (August 19). Available from: http://www.scmp.com/news/china/society/article/2005792/divorce-celebrities-sparkstalk-about-state-modern-marriage-china [Accessed 14 January 2018]

Yau, Esther, 1996. Compromised liberation: the politics of class in Chinese cinema of the early 1950s. In David E. James and Rick Berg, eds. The hidden foundation: cinema and the question of class. Minneapolis: University of Minnesota Press, 138-171. 